\title{
B- and T-Lymphocyte Attenuator
}

National Cancer Institute

\section{Source}

National Cancer Institute. B-and T-Lymphocyte Attenuator. NCI Thesaurus. Code C82851.

B- and T-lymphocyte attenuator (289 aa, $\sim 33 \mathrm{kDa}$ ) is encoded by the human BT LA gene. This protein is involved in the regulation of immune responses. 